\title{
EU Banking Union: Lessons for non-eurozone Transition countries ${ }^{2}$
}

\author{
Article history: \\ Received: 4 February 2015 \\ Sent for revision: 10 February 2015 \\ Received in revised form: 6 April 2015 \\ Accepted: 11 May 2015 \\ Available online: 2 July 2015
}

\begin{abstract}
Eurozone has gone through turmoil of sovereign debt crisis just after the detrimental effect of global financial crises of 2007/2008. Sovereign debt crisis of the eurozone was caused by bank-sovereign interdependence and lack of fiscal union in the eurozone. Financial fragmentation in the eurozone financial markets was an immediate outcome. Banking union of the $E U$ is a regulatory and institutional remedy for main financial problems of the eurozone post global financial crisis. It is clear signal that lessons have been learned from the two crises. Stricter regulation (single rule book) aims to increase the quality of banks. Single Supervisory Mechanism (SRM), and Single Resolution Mechanism (SRM) aim to unify and better the standards of supervision and resolution in the EU. With emphasis on bail-ins, and EU level backstops, bank-sovereign interdependence should be dismantled and chances of financial crisis reoccurrence with huge costs for taxpayers should be significantly lower. There are important elements of Banking Union that could be introduced in non-eurozone transition countries both members and nonmembers of the EU.
\end{abstract}

Keywords: Banking Union, EU, Sovereign debt crises, non-eurozone countries.

\footnotetext{
${ }^{1}$ Associate Professor, Faculty of Economics, University of Belgrade, soskic@ekof.bg.ac.rs

${ }^{2}$ This paper is a result of a project, "Risks of Financial Institutions and Markets in Serbia - Microeconomic and Macroeconomic approach", (project code179005), funded by Ministry of Education, Science and technological development of Republic of Serbia.
} 


\title{
Bankarska unija EU: pouke za zemlje u tranziciji van eurozone
}

\begin{abstract}
Apstrakt: Evrozona je odmah nakon negativnog uticaja globalne finansijske krize 2007./2008. prošla kroz izrazitu nestabilnost krize suverenog duga. Kriza suverenog duga unutar evrozone izazvana je međuzavisnošću bankarske $i$ državne finansijske stabilnosti i nepostojanja fiskalne unije unutar evrozone. Neposredni ishod ove krize bila je finansijska fragmentacija unutar finansijskih tržišta evrozone. Bakarska unija je regulatorni i institucionalni odgovor EU na glavne finansijske probleme eurozone nakon globalne finansijske krize. Ona je jasan signal da su lekcije naučene iz dve krize koje su se desile. Strožija regulacija (single rule book) ima za cilj podizanje kvaliteta banaka. Jeinstveni mehanizam regulacije (SRM), i Jedinstveni mehanizam sanacije i likvidacije (SRM) imaju za cilj da ujedine i podignu na viši nivo standarde supervizije $i$ sanacije i likvidacije banaka u EU. Sa naglaskom na internom podnošenju troškova gubitaka (bail-ins), i finansijskom podrškom na nivou EU, međuzavisnost bankarske $i$ državne finansijske stabilnosti bi trebalo da se razgradi, a verovatnoća ponovnog izbijanja krize sa visokim troškovima za poreske obveznike bi trebalo da je znatno manja. Postoje značajni elementi Bankarske unije koji se mogu primeniti u tranzicionim zemljama van eurozone i to kako članicama tako i nečlanicama EU.
\end{abstract}

Ključne reči: Bankarska unija, EU, kriza suverenog duga, zemlje van eurozone

\section{Introduction}

Spillover of US financial crises into EU financial markets at the end of 2007 and beginning of 2008 has provoked two waves of financial turmoil and adequate policy responses within the EU.

First wave of financial crises has primarily adversely influenced the quality of bank assets and has deteriorated capital adequacy, creating uncertainty and the necessity for government support of banking industry. It has also clearly emphasized the contradiction between nationally based supervision and international and cross boarder nature of banking and other financial institutions' operations. Policy response to this adverse influence was mainly in the area of new stricter regulation (CRD IV based on Basel III) and the creation of new supervisory EU level institutions: European Banking Authority (EBA), European Insurance and Occupational Pensions Authority (EIOPA), and European Securities and Markets Authority (ESMA). Also, European Systemic Risk Board (ESRB) was created to monitor potential threats to 
financial stability. In addition, European Stability Mechanism (ESM) was created as a permanent mechanism of financial stability support ${ }^{3}$.

Second wave of financial crises started with the rising concerns about fiscal sustainability of certain eurozone countries. Perception of the markets was starting to be that not all Eurozone sovereigns ${ }^{4}$ are low risk. It was a concern, more and above the Greek sovereign debt crises, and dealing with an issue whether certain countries have the fiscal capacity to bear the costs of bank resolutions under their jurisdictions, since bank balance sheets have deteriorated since the crises. Banks in the EU were still "European in life and national in death". This was putting an additional pressure to borrowing costs not just for sovereign but also for corporate sectors. Since banks are holding exposures to both sectors in their balance sheets (with direct holdings of financial assets, but also with off balance sheet products such as guarantees and/or credit default swaps), any deterioration in the quality of sovereign and corporate sectors would produce further deterioration in the quality of bank assets. This on the other hand, increases the risks of higher resolution costs, further deteriorating the quality of government bonds. This vicious circle between banks and sovereigns and financial market segmentation within the eurozone, had to be dealt with. At one point in time Credit rating agencies were perceived as a main cause of this problem, and that the solution would be to try to dismantle the link between the credit ratings of traditional rating agencies and the sovereign cost of borrowing. However, soon it was realized that solution to this problem has to be a fundamental and comprehensive step forward in the direction of further integration of eurozone financial markets: creation of the Banking Union.

\subsection{Literature overview}

The research literature on EU Banking Union is fairly recent and dynamic, The structure itself has been announced in 2012 and has been moulded through discussions and in the following years. Therefore, literature is still not numerous and often is based on original documents produced by EU and ECB.

For the purpose of this research of particular importance is the following literature. Paper by Paper by Freixas (2010), prior to EU sovereign-debt crisis, has underlined the necessity of bail-in instruments in post crisis bank regulation. Pisani-Ferry $(2012 a)$ has clearly underlined the necessity of creation of EU Banking Union if eurozone bank-sovereign interdependency is to be dismantled. Pisani-Ferry, Sapir, Véron \& Wolff (2012b) thoroughly

\footnotetext{
${ }^{3}$ Following two temporary institutions: European Financial Stability Mechanism (EFSM), and European Financial Stability Facility (EFSF).

${ }^{4}$ We will be using the term "sovereign" in the meaning of national, government (debt).
} 
analyze seven open issues in creation of the Banking Union. Pisani-Ferry \& Wolff (2012c) clearly state that banking crises goes with fiscal costs and propose several models of fiscal backstop for the EU Banking Union. Elliot (2012) gives a complete overview of a Banking Union structure with various options, but also discusses the implications of potential eurozone exit, and interaction of non-eurozone U.K. and the Banking Union. Weidmann (2013) argues that Banking Union is vital for Monetary Union but raises issues that need to be resolved if Banking Union is to succeed. Moloney (2014) estimates the robustness of Banking Union given the complex political, institutional and EU Treaty environment. Bremus \& Lambert (2014) are analyzing accomplished so far, but also stress the need to do more in order to disentangle bank-sovereign interdependence.

Contribution of this paper to the literature should be to provide an overview of causes and consequences of creation of the EU Banking union with an emphasis on the effects it can have on non-eurozone transition countries, both the ones that are in the EU and the ones that are not EU members.

\section{Prelude to EU Banking Union: Financial fragmentation and Bank-sovereign interdependence}

Financial crisis of 2007/2008 came within the EU that had 27 different regulatory systems for banks, no tools to deal with large cross-border banks and a single backstop for banking losses with national budgets. No other EU backstop facility was available. Banks were "European in life and national in death". Entirely national perspective concerning bank regulation, supervision, and resolution were not sufficient for the posed challenge. No eurozone crises management framework had been put in place to support national resolution capacities. Such a framework was prone to large fiscal burdens on national government levels ${ }^{5}$ (European Commission, 2013), and vicious circles between banks and national finances. As an aftermath, it was not a surprise to go through sovereign debt crises and financial fragmentation within a eurozone.

\subsection{Financial fragmentation}

When markets started to perceive sovereign debt risks differently among the countries of the eurozone, financial market segmentation was in motion. Fragmentation of financial markets within the eurozone was taking the form of

\footnotetext{
${ }^{5}$ Approved state aid in the EU (recapitalization and asset relief measures) between October 2008 and December 2012 amounted to 591,9 billion Euros or 4,6\% of EU 2012 GDP. With guarantees the figure rises to 1.600 billion Euros or $13 \%$ of EU GDP for the period 2008-2010 only.
} 
increased influence of country specific effects on financial market conditions both on sovereign debt markets (Figure 1) and on corporate debt markets (Figure 2). It was a complete contrast to the 1999-2008 period in which euro as a single currency has integrated the eurozone money market and has led to almost complete convergence of borrowing costs for corporate and sovereign borrowers. Financial crises, however, has proved that this financial convergence was fragile in a not completely integrated eurozone i.e. lacking fiscal union.

Figure 1. Divergence in sovereign borrowing costs in five largest eurozone economies: yields on 10 year government bonds (\% Ihs) and coefficient of variation (rhs).

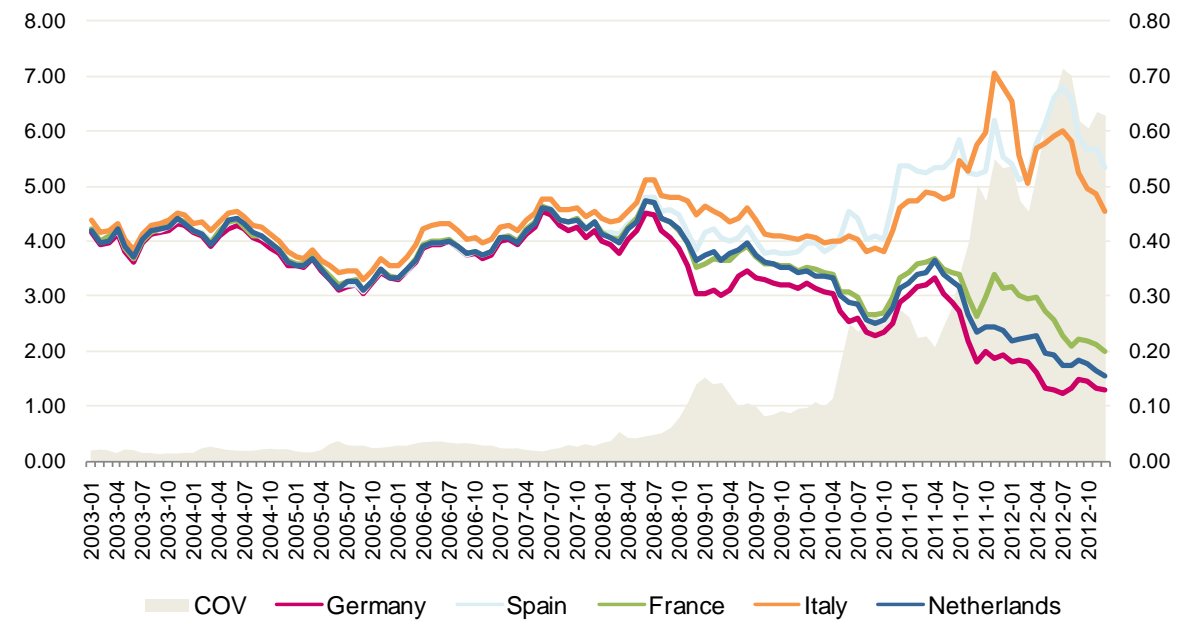

Source: ECB statistical data warehouse (EBRD, 2012).

Deterioration in borrowing costs of eurozone periphery did not just emphasize the questionable fiscal sustainability of these countries in light of new, higher sovereign borrowing costs, but has decreased economic growth both as a result of declining government financed consumption and investments, and decreased real private sector growth due to deteriorating corporate borrowing costs. Decreasing economic growth in eurozone periphery has additionally pressured their fiscal sustainability since most often in new circumstances the growth rate was below current sovereign interest rate, exerting additional pressure on debt level in relative terms to GDP.

Lack in economic growth in eurozone periphery has initiated disinflationary and deflationary pressures, additionally raising the real cost of borrowing both for sovereigns and for corporates in these countries. 
Figure 2. Divergence in corporate borrowing costs in five largest eurozone economies: interest rate on short term loans to corporates (\% Ihs) and coefficient of variation (rhs).

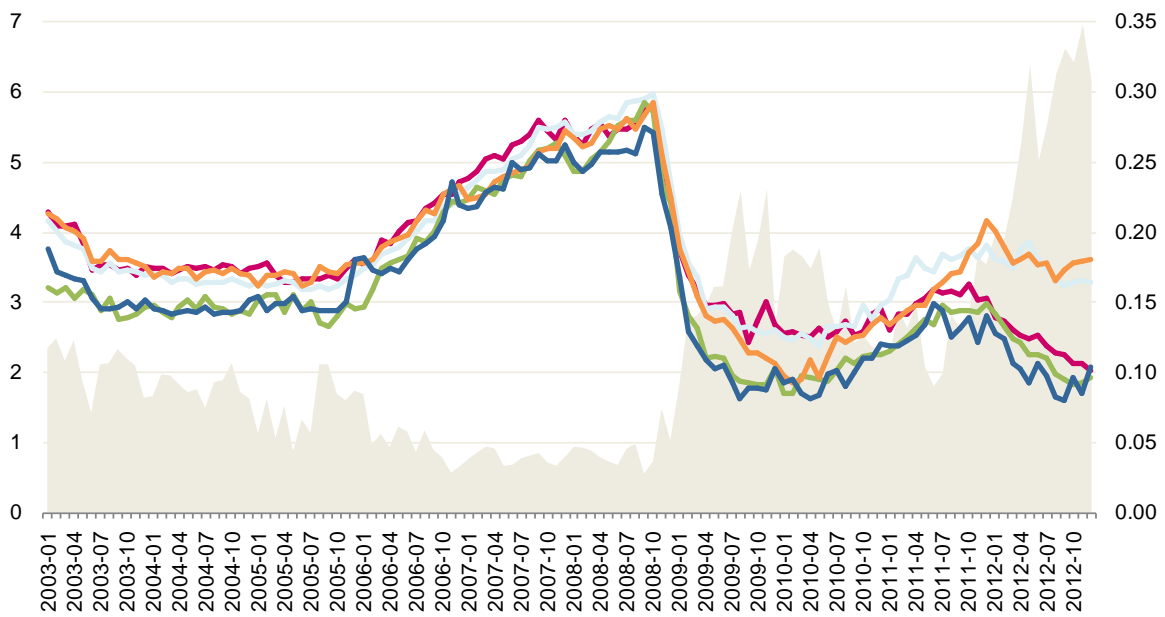

Cov — Germany - Spain -France -Italy - Netherlands

Source: ECB statistical data warehouse (EBRD, 2012).

\subsection{Bank-sovereign interdependence}

The problem of financial fragmentation and sovereign debt crises in eurozone was predominantly influenced by bank-sovereign interdependence. Whenever you have significant leverage and/or non-performing loans (NPLS) alongside a substantial exposure of banks to sovereigns, economic contraction can produce a negative spiral between worsening bank balance sheets and erosion of national government financial position (Figure 3.) which in turn again negatively influences the bank balance sheets. This is reliant on a premise that the central bank is not allowed to finance the government (or provide equity financing for the failing banks) and that the national government is the only backstop for failing systemic banks. And that has been the case, as we know, in all eurozone countries.

However, there are only several possible remedies to this problem. The first is to allow the ECB to lend to sovereigns. This solution is in clear breach of the no-monetary financing of the EU Treaty. The second option is to have coresponsibility for public debt in the eurozone i.e. a Fiscal union. This solution 
is not yet politically available. The third remaining option is to have a Financial union, and in the case of eurozone finance, where the bank credit is a predominant financial instrument, that meant the creation of the Banking union. In other words, it is not possible to have no co-responsibility for public debt, strict no-monetary financing, and no bank-sovereign interdependence.

Figure 3. Vicious circle between banks and national finances

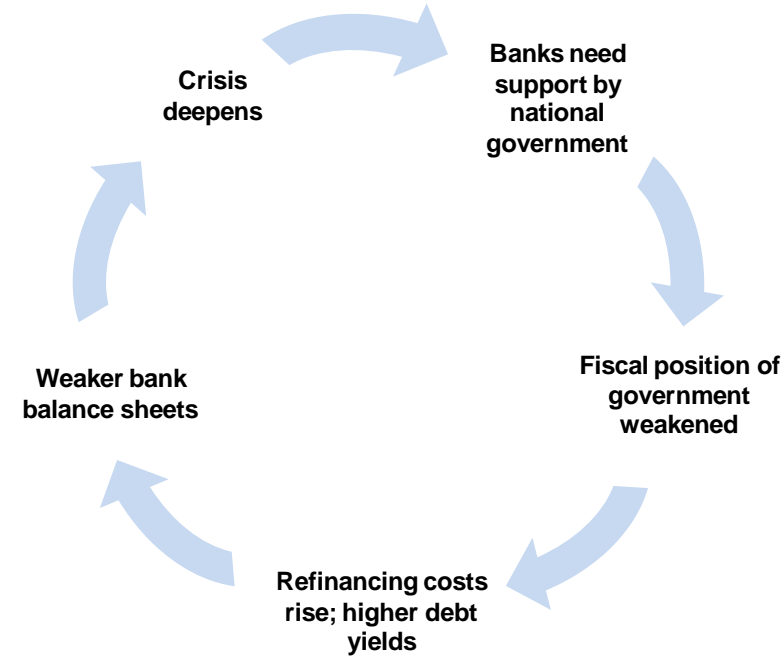

Source: European Commission 2014.

The current eurozone structure (Figure 4.) had to change towards the creation of the BU in order to disentangle the vicious circle of bad bank balance sheets and bad public finance. One can see that this as an available move in a necessary direction, which can be implemented even before the Fiscal union can be constructed in a way that is politically acceptable for all the eurozone countries. Despite the fact that BU is a project specifically designed for EMU and EU countries, there are several very important elements of this project that could be important for, and implemented within the countries outside of eurozone. 
Figure 4. The new trilemma ${ }^{6}$

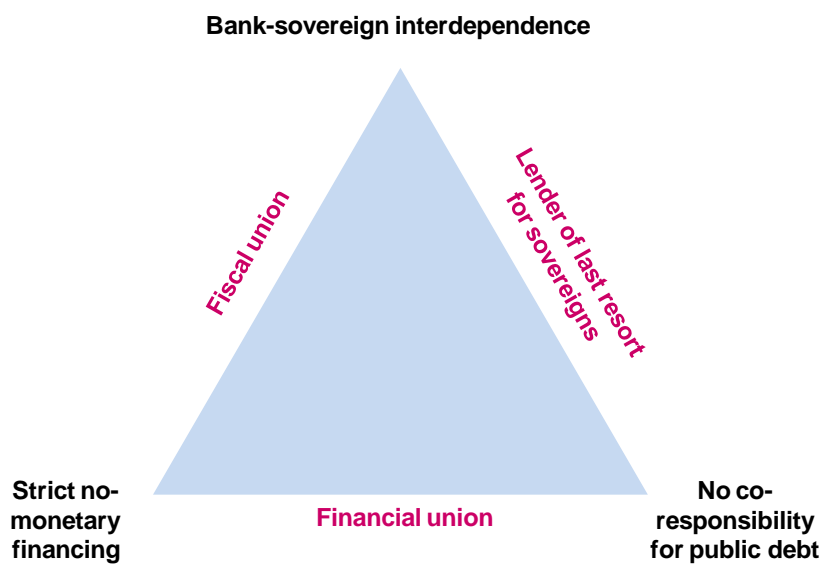

Source: Pisani-Ferry, 2012a, pp.8.

\section{Structure of the Banking Union}

EU heads of states committed to EU banking Union in June 2012. The Banking Union (BU) is a natural step forward in development of Economic and Monetary Union (EMU). One could argue that the BU is a crucial pillar of EMU alongside Economic Union, Fiscal Union, and Political Union (Draghi, 2012), and that its development, in the eyes of many, was long overdue.

A strong basis for creation of the Banking union was a well-developed socalled single rule book i.e. legal acts that all banks in the EU must comply with. These include: Capital Requirements Regulation (CRR) and Capital Requirements Directive IV (CRD IV), Directive on deposit guarantee schemes (DGS), and Bank recovery and resolution directive (BRRD). These new rules are designed to make banks much safer, resilient to crises, and to protect deposits of EU citizens up to 100.000 euros in all member states.

Besides a single rule book, there are two essential elements of the Banking union: Single Supervisory Mechanism (SSM), and Single Resolution Mechanism (SRM). Banking union can operate only if supervision and resolution are done on the eurozone level, so to eliminate potential different approaches to supervision and implementation of a single rule book, and to avoid different national approaches to dealing with ailing banks. In addition,

6Refereeing to the old trilemma of Mundell-Fleming model that you cannot have a flexible exchange rate, free capital flows, and independent monetary policy at the same time. 
adequate supranational financial backing is vital so to dismantle the banksovereign vicious circle and financial market segmentation.

However, if single rulebook requires better capitalization ${ }^{7}$, better liquidity and better risk control on the side of the banks, and if there is unified high quality supervision led by ECB and national supervisors in an integrated system within SSM, risks for bank insolvencies should be far lower in the future. Even if they materialize, troubled banks should be dealt by a unified truly European SRM. Potential financial assistance for troubled banks should come in the following order: writing of certain liabilities and/or converting them into equity (so-called bail-in), tapping to funds that the banks themselves pay in to, and finally as a last resort, use of public (taxpayers funds) but with neutral midterm fiscal effect ${ }^{8}$. Therefore, protection of tax-payers is in the core of Banking union.

Countries outside of eurozone are eligible to join the EU Banking union.

\subsection{Single Supervisory Mechanism}

As with any regulation, without good supervision, regulation can be worthless. The main component of Banking Union is establishment of a single supervisor for eurozone credit institutions. That role has been designated to the European Central Bank (ECB) and it has assumed that responsibility on November $4^{\text {th }} 2014$ (ECB, 2014b). ECB supervises directly 120 significant banking groups whose assets represent $82 \%$ of the euro area bank assets. Remaining less significant 3,500 banks will be supervised by national supervisors but with ECB setting and monitoring the supervisory standards (ECB, 2014a).

Prior to taking over the responsibilities of a single eurozone supervisor, a year-long assessment of the banking system was conducted by the ECB, so called "comprehensive assessment". It was a financial health check of 130 banks (baking groups) in the euro area ${ }^{9}$. Comprehensive assessment covered around $82 \%$ of total bank assets, and it was conducted by ECB and national supervisors between November 2013 and October 2014. Comprehensive assessment was consisted of two components:

\footnotetext{
7 Under CRD IV (based on Basel III), additional better loss absorbing capitalization (Common Equity Tier 1 capital -CET1) is envisaged for all banks (2\% - Basel II, 4,5\% - Basel III), with additional requirements for CET1 in the form of capital conservation buffer (2,5\%), and Countercyclical capital buffer $(0-2,5 \%)$. In addition to that, Systemically important financial institutions (SIFIs) should hold additional CET1 capital (1-2,5\%), and individual banks if their risk profile requires stronger capitalization (under Pillar II of Basel III). (CRD IV, 2013).

8 Whatever public funds were used should be paid back.

9Including Lithuania which at the time was not a member of Eurozone, but was scheduled to become on January 1st 2015.
} 
- $\quad$ Asset quality review of selected banks

- Stress test, testing the resilience of banks' balance sheets to two adverse scenarios.

That was a precondition for the Single Supervisory Mechanism to start operating. Report of the exercise was presented in October 2014 (ECB, 2014c) with twenty five banks with the capital shortfall in adverse scenario stress testing in the amount of 25 billion euros.

The Single Supervisory Mechanism (SSM) is based on the activities of the ECB and the national supervisors - so called national competent authorities (NCAs) of specific eurozone countries. There are three main objectives of $\operatorname{SSM}(E C B, 2014 d)$ :

- $\quad$ ensure the safety and soundness of the European banking system;

- $\quad$ increase financial integration and stability;

- ensure consistent supervision.

Among the member states participating in SSM, credit institutions are categorized as significant and less significant. The ECB is supposed to directly supervise the significant credit institutions. The national supervisors are entitled to supervise the less significant banks. But direct and continual cooperation between the ECB and the National supervisors needs to exist at all times.

Supervisors are given extended powers to intervene early within the distressed banks (dismissal of managers, adoption of urgent reforms by shareholders, prohibiting dividends, bonuses, reducing exposures, increase of capital, imposition of changes to legal and corporate structures) even before the bank is in breach of regulatory capital requirements.

\subsection{Single Resolution Mechanism}

The Single Resolution Mechanism (SRM) is a second major component of the banking union. SRM is designed to unify vital competences and resources for managing the failure of banks on EU level. If SSM detects a failing bank and is unable to improve its situation with means at its disposal, resolution of the bank is to be delegated to SRM so to manage it efficiently and with minimal costs in terms of taxpayers' money and growth of the real economy. Intensive cooperation between SSM and SRM, including reviewing of resolution plans, are of key importance for this process to be effective. Information sharing and coordination in supportive actions are essential for prevention of untimely actions and duplications of tasks.

Almost all credit institutions (about 6000) in countries of the banking union will be under direct responsibility of SRM. The SRM is comprised of a Single 
Resolution Board and a Single Resolution Fund, financed by the banking sector.

Single Resolution Board is the main decision making authority of SRM and will closely cooperate with the national resolution authorities of countries within a banking union. The Board is established in August 2014 and is an independent EU agency financed by bank contributions. When being notified by the ECB that a bank is failing or about to fail, the Board will design a resolution structure with set of tools and potential usage of financial resources from a Single Resolution Fund. Available resolution tools are the following (SRM Regulation, 2014):

- $\quad$ the sale of business tool;

- $\quad$ the bridge institution tool;

- $\quad$ the asset separation tool;

- the bail-in tool.

Resolution process closely involves national authorities responsible for bank resolution, with the Board supervising their activities and directly intervening in failing banks if necessary. Single resolution fund is controlled by the Board and with a task to support resolution with medium-term funds. The Fund will be gradually developed to the size of $1 \%$ of covered deposits in the banks of the Banking union from 2016 to 2024 (with a possibility to extend this period for additional four years). In terms of the size of bank balance sheets of 2011, fully funded Single Resolution Fund should equal around 55 billion euros.

The Board may use the Fund only to support resolution tools and for the following purposes (SRM Regulation, 2014):

- to guarantee the assets or the liabilities of failing bank, a bridge institution or an asset management legal entity;

- to make loans to the failing bank, a bridge institution or an asset management legal entity;

- to purchase assets of the failing bank;

- to make contributions to a bridge institution and an asset management legal entity;

- to pay certain compensation to shareholders in specific circumstances if they incurred greater losses then in winding down of a failing bank;

- to make a contribution to the failing bank when the bail-in tool is applied and the decision is made to exclude certain creditors from the scope of bail-in. 


\subsection{Other important aspects of the Banking Union}

Despite initial intentions to create a Single Depositary Guarantee Scheme (DGS) on Banking union level, a pan - EU DGS is not currently under discussion. There is a relatively high level of harmonization of DGS across Europe since a new DGS Directive was enacted in 2014. Current legislation (DGS Directive, 2014) allows only for a voluntary mechanism of mutual borrowing between national DGS from different countries of the EU. This is the final level of mutualisation at this time and for the near future. Once the Banking union with all of its element is fully operational, a discussion on pan - EU DGS may potentially re-emerge.

Despite being founded to support sovereign states of the eurozone, European Stability Mechanism (ESM) within the Banking Union is eligible to provide assistance i.e. to recapitalize significant credit institutions directly circumventing the governments. In other words, this recapitalization would take place without official increase of government debt of a Member State. This recapitalization tool relies on full cooperation between ECB (SSM), ESM and national resolution authorities. The ECB needs to be involved in any negotiations between the ailing bank and the ESM concerning the terms and condition of the recapitalization. This direct involvement of the ESM is important, again, for the dismantlement of the bank-sovereign interdependence.

Table 1. Banking Union important dates

\begin{tabular}{|l|l|}
\hline Date & BU Milestone \\
\hline June $29^{\text {th }} 2012$ & $\begin{array}{l}\text { Euro-area leaders commit to the Banking } \\
\text { Union. }\end{array}$ \\
\hline September $12^{\text {th }} 2012$ & $\begin{array}{l}\text { European } \\
\text { proposals for SSM to make ECB } \\
\text { supervisor of all eurozone banks. }\end{array}$ \\
\hline October $8^{\text {th }} 2012$ & ESM becomes operational \\
\hline April $18^{\text {th }} 2013$ & $\begin{array}{l}\text { EU approves law to turn ECB into } \\
\text { eurozone bank supervisor }\end{array}$ \\
\hline June $20^{\text {th }} 2013$ & $\begin{array}{l}\text { Euro area agrees that ESM can } \\
\text { recapitalize banks directly }\end{array}$ \\
\hline July $14^{\text {th }} 2104$ & \begin{tabular}{l} 
EU governments approve SRM \\
\hline November $4^{\text {th }} 2014$ \\
bank supervision
\end{tabular} \\
\hline January $1^{\text {st }} 2015$ & $\begin{array}{l}\text { SRM starts and banks start paying levies } \\
\text { into national resolution funds. }\end{array}$ \\
\hline January $1^{\text {st }} 2016$ & $\begin{array}{l}\text { Single Resolution Fund starts and } \\
\text { BU is fully operational }\end{array}$ \\
\hline January $1^{\text {st }} 2024$ & $\begin{array}{l}\text { Deadline for SRF to have resources } \\
\text { equivalent to 1\% of covered deposits }\end{array}$ \\
\hline
\end{tabular}


Prior to ESM Direct recapitalization instrument, ailing bank would need to tap into bail-in of private investors, and national and/or Single Resolution Funds. Even the DGS funds may be used for resolution purposes. Therefore, public funds are last in line of available supporting financial instruments, after private and banking funded resources have been used.

All of the components of the Banking union are set to become fully operational from January $1^{\text {st }} 2016$.

\section{Lessons for non-eurozone transition countries}

Banking Union is very relevant for non-eurozone transition countries. Fact is that on average foreign-owned banks hold $72 \%$ of banking assets in Eastern Europe and just 14\% of banking assets in Western Europe (EBRD, 2012), and that that most of these foreign-owned banks in the East are owned by banks from eurozone. Therefore, Banking Union, and its regulation, supervision and resolution will be indirectly present in non eurozone transition countries as well.

Figure 5. Asset share of foreign/owned banks in national banking systems in \%

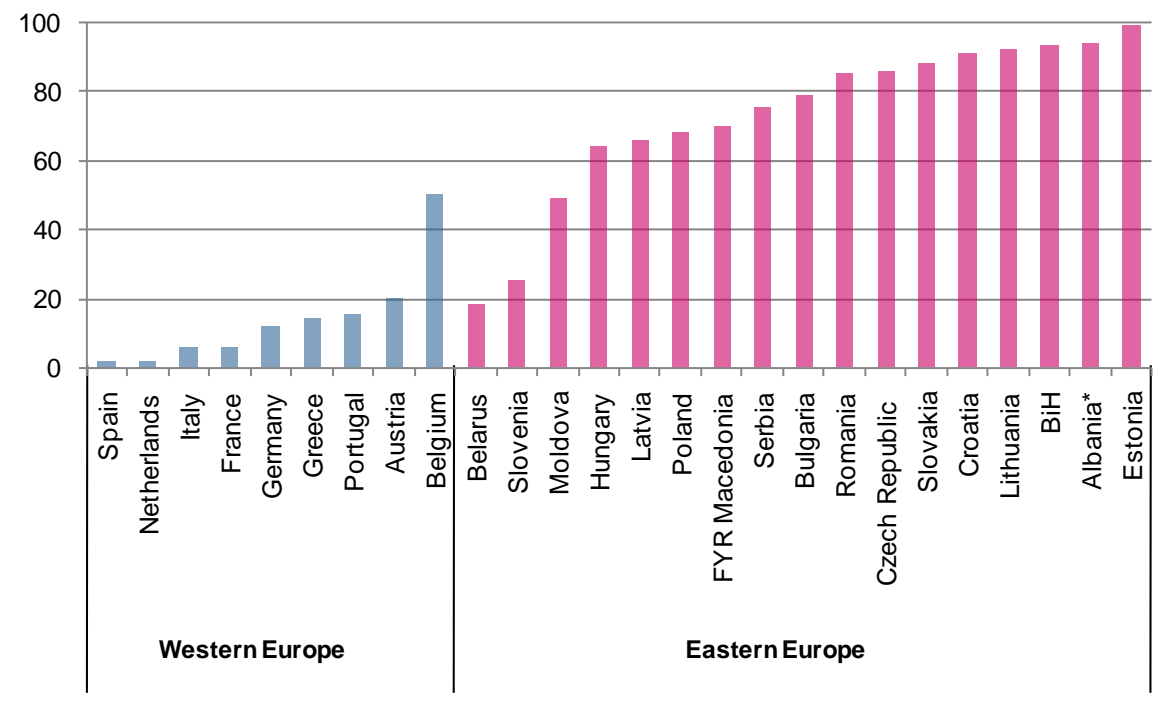

Note $\left(^{*}\right)$ : Data for Albania refer to 2008

Source: Claessens \& Van Horen (2012) 
However, let us focus on the sovereign debt crises in Europe, creation of BU, and the valuable lessons and guidelines for non-eurozone countries.

The creation of the $\mathrm{BU}$ relies on the will to make banks stronger and more immune to shocks. This is a basic principle of creation of a more sound financial system, less prone to be exposed to losses it cannot sustain. This point has a regulatory and a supervisory aspect and both are applicable in non-eurozone transition countries.

First, regulatory aspect relates to implementation of Basel III standards (which are already implemented in the EU through CRD4). Implementation of these standards will provide more quality capital base and liquidity for the banks and insure their strength and immunity to shocks, especially for systemically important banks. This also includes possibilities under pillar II, which are very important but seldom used ${ }^{10}$. This is a very important element in providing more loss absorption capacity on the side of the banks, and less risk of additional government i.e. taxpayers' expenditures in case of further bank insolvencies. Non-eurozone transition countries very often are lagging behind in Basel III implementation and have an extended period of regulatory adjustment in this field. Since the banking sectors of transition countries are frequently burdened with relatively high levels of NPLs, and since some recent bank failures have caused substantial burden for an already fragile fiscal position of some of the transition countries, it might be wise to consider earlier adoption of Basel III standards among non-eurozone transition countries. These standards, as we have seen, represent a significant portion of the so-called Single rule book of the BU.

Second, supervisory aspect relies on increasing the supervisory capacity of an existing regulator. In case of $\mathrm{BU}$ it includes the conduct of Asset Quality Review (AQR) of the bank balance sheets and implementing stress tests that are realistic for the banks to endure in case of severe financial crises. As in the case of $\mathrm{BU}$, where prior to the ECB engagement as a single supervisor for the whole EMU, thorough screening and stress testing has been done to expose the strengths and weaknesses of the banking sector, non eurozone transition countries should submit their banking sectors to the similar process to create a realistic vision of the risks and weaknesses to be addressed preemptively. Therefore, increasing the institutional capacity and realistic fact finding going on in the process of BU creation are needed and desirable in the non-eurozone transition countries as well.

Third, very important aspect of the BU framework is creation of a more effective early intervention system on the side of a supervisor. The same is direly needed most of the non-eurozone transition countries. Hand in hand with the need to increase the capacity of central banks to detect problems in

10 Pillar II of Basel standards allows for additional capital buffers required for bank specific risks. 
the banking sector early, the supervisor needs to have powers to react to these findings without delay i.e. significantly before capital and liquidity parameters are below the required levels, and sometimes, beyond realistic and swift repair. As in the case of $\mathrm{BU}$, these may include demanding recovery plans from the banks, dismissal of the management and appointment of special manager, waiver of distribution of dividends and bonuses, forceful reduction of certain exposures, increase in capital, and mandatory changes to legal or corporate structures of the bank. All of these measures foreseen by the $\mathrm{BU}$ to be delegated to the supervisor are eligible to be potentially implemented in non-eurozone transition countries as well.

Fourth, bank-sovereign interdependence is not solely a eurozone problem. This loop is a potential problem of any other non-eurozone transition country and should consider policies to reduce this risk. If public debt monetization is not allowed i.e. a central bank is not allowed to serve as a lender of last resort to sovereigns, a vicious circle of bank-sovereign interconnectedness has to be contained otherwise. One of the possible ways available for non-eurozone transition countries is to potentially limit bank exposure do local government debt. At the same time, from a point of view of bank-sovereign interdependence, re-evaluation of monetary policy instruments and collaterals acceptable by central banks could be in place.

Fifth, corporate governance and information asymmetry between owners and executives could be part of a supervision process and pre-emptive measures of a bank supervisor. This can prove to be important, since failing banks frequently, had low corporate governance efficiency. Since ECB now has powers to impose mandatory changes to legal or corporate structures of the bank, similar authorities by the supervisors in non-eurozone transition countries designed to improve corporate governance efficiency of banks could prove useful.

Finally, BU introduces a very important principal of significantly reducing the possibility of using tax payers' money to finance bank bailouts. Especially if the fiscal position of the country is relatively fragile, this principal deserves to be thoroughly analyzed and implemented as much as possible. The "too big to fail" and excessive bail-outs should be the thing of the past. Alongside stricter regulation, better supervision and pre-emptive measures, bail-ins and orderly resolution of insolvent banks should be the final important element of the BU principles that could be implemented in non-eurozone transition countries. The clear system of private bail-ins, and bank funded resolution fund is a very much needed improvement of the banking system for many transition countries, especially the ones with fiscal challenges. For the banks which prove to be unviable, winding down of their operations and orderly resolution without stress implications to the rest of financial system is vital. In most transition countries there is still substantial room to improve the 
resolution process to be much less expensive for the taxpayers and yet without financial stability consequences.

As we can see, Banking Union has been enacted as a project designed to help overcome the problems of dual financial crises in the EU, and with a goal to establish a more robust financial system capable of substantially decreasing the risk of future taxpayers' money involvement in banking bailouts. However, despite the fact that such a project has been developed to address the specific problems and issues in the eurozone, it has also developed universal principles and ideas for improvements in national and regional financial systems throughout the world. Non-eurozone transition countries, as we have seen, also have a number of very useful guidelines and specific measures that can be drawn from the principles and the mechanisms of the EU Banking Union.

\section{References}

Alter, Adrian, \& Yves S. Schuler, (2012), "Credit Spread Interdependencies of European States and Banks During the Financial Crisis." Journal of Banking and Finance, 36(12): 3444-3468.

Bremus, Franziska \&, Lambert, Claudia, (2014) "Banking Union and Bank Regulation: Banking Sector Stability in Europe" DIW Economic Bulletin, November, Vol. 4 Issue 9, Pp. 29-39.

BRRD Directive (2014), "Directive 2014/59/EU Of The European Parliament And Of The Council of 15 May 2014 establishing a framework for the recovery and resolution of credit institutions and investment firms and amending Council Directive 82/891/EEC, and Directives 2001/24/EC, 2002/47/EC, 2004/25/EC, 2005/56/EC, 2007/36/EC, 2011/35/EU, 2012/30/EU and 2013/36/EU, and Regulations (EU) No 1093/2010 and (EU) No 648/2012, of the European Parliament and of the Council," Official Journal of the European Union L 173/190

Claessens, S. \& Van Horen N. (2012) "Foreign banks: trends, impact and financial stability", IMF Working Paper No.12/10, Washington, D.C.

CRD IV (2013), "Directive 2013/36/EU of the European Parliament and of the Council of 26 June 2013 on access to the activity of credit institutions and the prudential supervision of credit institutions and investment firms", Official Journal of the European Union L 176/338.

DGS Directive (2014), "Directive 2014/49/EU of the European Parliament and of the Council of 16 April 2014 on deposit guarantee schemes", Official Journal of the European Union L 173/149.

Draghi, Mario, (2013) "The role of monetary policy in addressing the crisis on the euro area", Speech by Mario Draghi, President of the ECB, at the "Room for Discussion" of the Study Association SEFA and the Faculty of Economics and Business, Amsterdam, 15 April 2013, http://www.ecb.europa.eu/press/key/date/2013/html/sp130415.en.html 
EBRD (2012), Transition Report 2012: Integration Across Boarders, European Bank for Reconstruction and Development, London.

ECB (2014a), The list of significant supervised entities and the list of less significant institutions, Latest update of the list: 04/09/2014, European Central Bank.

ECB (2014b), "ECB assumes responsibility for euro area banking supervision", Press Release, 4 November 2014.

ECB (2014c), Aggregate Report on the Comprehensive Assessment, European Central Bank, October 2014.

ECB (2014d), Guide to banking supervision, European Central Bank, November 2014.

Elliot, Douglas J. (2012) "Key Issues On European Banking Union: Trade-Offs And Some Recommendations", Global Economy \& Development Working Paper , 52, , November, Brookings Institution.

European Commission, 2014, "Banking union: restoring financial stability in the Eurozone“, Memo, Brussels, 15 April 2014, http://europa.eu/rapid/pressrelease MEMO-14-294 en.htm

European Commission, 2013, "State aid: Commission's new on-line state aid benchmarking tool shows less aid to banks", Press Release, Brussels, 20 December 2013, http://europa.eu/rapid/press-release IP-13-1301 en.htm

European Commission (2014) "Single Resolution Mechanism for the Banking Union" Memo, Brussels, 15 April 2014, http://europa.eu/rapid/press-release MEMO-14295 en.htm?locale=en

Freixas, Xavier (2010) "Post-crisis challenges to bank regulation", Economic Policy, (62), p.375-399.

Moloney, Niamh (2014) "European Banking Union: Assessing its risks and resilience", Common Market Law Review, December, Vol. 51 Issue 6, p1609-1670. 62p.

Pisani-Ferry, Jean, (2012a) "The Euro Crisis and the New Impossible Trinity", Bruegel Policy Contribution, Issue 2012/1, January 2012, http://www.bruegel.org/publications/publication-detail/publication/674-the-eurocrisis-and-the-new-impossible-trinityl

Pisani-Ferry, J., Sapir A., Véron N. \& Wolff G.B. (2012b) "What Kind or European Banking Union", Bruegel Policy Contribution, Issue 2012/12, Jun 2012, http://www.bruegel.org/publications/publication-detail/publication/731-what-kindof-european-banking-union/ .

Pisani-Ferry, J. and Wolff, G.B. (2012c) "The Fiscal Implications of a Banking Union" Bruegel Policy Contribution, Issue 2012/02, September 2012, http://www.bruegel.org/publications/publication-detail/publication/748-the-fiscalimplications-of-a-banking-union/ .

SRM Regulation (2014) "Regulation (EU) No 806/2014 of the European Parliament and of the Council of 15 July 2014 establishing uniform rules and a uniform procedure for the resolution of credit institutions and certain investment firms in the framework of a Single Resolution Mechanism and a Single Resolution Fund and amending Regulation (EU) No 1093/2010", Official Journal of the European Union, L 225/1.

Stolbov, Mikhail (2014) "How are Interbank and Sovereign Debt Markets Linked? Evidence from 14 OECD Countries, the Euro Area and Russia." Panoeconomicus, 3:331-348.

Weidmann, Jens (2013) "Banking Union Properly Structured", The International Economy, Winter. 